\title{
Determinants of Job Performance among Medical Rehabilitation Health Personnel at Dr. Moewardi Hospital, Surakarta, Central Java: A Path Analysis Evidence
}

\author{
Sisybania'), Mahendra Wijaya'2), Bhisma Murti') \\ ${ }^{1)}$ Masters program in Public Health, Universitas Sebelas Maret \\ 2)Faculty of Social and Political Science, Universitas Sebelas Maret
}

\section{ABSTRACT}

Background: The quality of a health institution is determined by human resources (HR) and the quality of staff services. The quality of health human resources is measured by employee performance and productivity especially services that are directly related to patients, such as the Department of Medical Rehabilitation. This study aimed to analyze the psychosocial economic determinants of the performance of medical rehabilitation health personnel.

Subjects and Method: This study used a crosssectional method. This study was conducted from May 2020 to June 2020. The sample was selected by exhaustive sampling by 200 medical rehabilitation health personnel at Dr. Moewardi, Surakarta. The dependent variable was performance. The independent variables were motivation, skill, work atmosphere, facilities and infrastructure, work experience, training, education, leadership style, incentive, reinforcement, vicarious learning, and observational learning. The data were collected using questionnaires and analyzed using path analysis with STATA version 13.

Results: Medical rehabilitation health personnel had a likelihood of performing well with parti- cipative leaders $(\mathrm{b}=2.24 ; 95 \% \mathrm{CI}=0.09$ to $1.44 ; \mathrm{p}=$ o.025), sufficient incentives $(\mathrm{b}=3.19 ; 95 \% \mathrm{CI}=$ 0.42 to $1.76 ; \mathrm{p}<0.001)$, high motivation $(\mathrm{b}=3.38$; $95 \% \mathrm{CI}=0.51$ to $1.93 ; \mathrm{p}<0.001$ ), by attending training and education for medical rehabilitation $(b=$ $1.86 ; 95 \% \mathrm{CI}=-0.03$ to $1.27 ; \mathrm{p}=0.064$ ), good reinforcement $(b=1.72 ; 95 \% \mathrm{CI}=-0.09$ to $1.42 ; \mathrm{p}=$ o.o86), training and education through incentives $(b=1.86 ; 95 \% \mathrm{CI}=-0.02$ to $1.11 ; \mathrm{p}=0.062)$, conducive work atmosphere through motivation $(b=2.49 ; 95 \% \mathrm{CI}=0.16$ to $1.42 ; \mathrm{p}=0.013)$.

Conclusion: The performance of medical rehabilitation health personnel is affected by leadership style, incentives, motivation, training and education, work atmosphere, and reinforcement.

Keywords: social cognitive, performance, path analysis

\section{Correspondence:}

Sisybania. Masters Program in Public Health, Universitas Sebelas Maret. Jl. Ir. Sutami 36A, Surakarta, Central Java. Email: sisybania@gmail.com. Mobile: +628976804589 .

Cite this as:

Sisybania, Wijaya M, Murti B (2021). Determinants of Job Performance among Medical Rehabilitation Health Personnel at Dr. Moewardi Hospital, Surakarta, Central Java: A Path Analysis Evidence. J Health Policy Manage. 06(01): 01-12. https://doi.org/10.26911/thejhpm.2021.06.01.01.

c) (i) (2) Journal of Health Policy and Management is licensed under a Creative Commons Attribution-NonCommercial-ShareAlike 4.0 International License.

\section{BACKGROUND}

Nowadays, the health care environment is changing rapidly. As a developing country, the medical needs of the Indonesian people are varied and the competition in medical services is increasing. Hospital is an organization that depends on human resources, the quality of staff services is crucial for the run- ning of the hospital system (Oh, 2019). To meet the quality of hospital services, the Minister of Health categorizes hospitals into several types according to the facilities and infrastructure available and the resources in it. The general hospitals are classified into Class A, B, C, and Class D (Ministry of Health RI, No 56, 2014). 
Based on the data in 2018, there were 289 hospitals in Central Java, consisting of 65 general hospitals, 12 hospitals belonging to the Indonesian Military/National Police, 210 private hospitals, and 2 hospitals belonging to other ministries (Central Java Health Office, 2018).

The quality of a health institution is determined by human resources (HR) and the quality of staff services. The quality of health human resources is measured by employee performance and productivity especially services that are directly related to patients, such as the Department of Medical Rehabilitation.

Hospitals that have medical rehabilitation services are Class A and Class B hospitals. Based on the data per April 2018, there were 472 hospitals. Region 1 included DKI Jakarta, Central Java, East Java, Banten, West Java, and Yogyakarta. There were 46 hospitals with Class A and 245 hospitals with Class B (Trisnantoro and Listyani, 2018).

Each organization, both public and private, requires the professionalism of human resources (HR) who have knowledge, skills, management capabilities, and mastery of technology. Therefore, skilled, educated, motivated, and disciplined labor would be created (Randungan et al, 2015). In many places, eachindividual has various skills and knowledge due to different educational backgrounds. Training or workshops are needed so that knowledge and skills are the same. In addition, it can improve service quality.

This is in line with the Social Cognitive Theory (SCT) that motivation determines how people behave like beliefs encourage people to do an activity. Therefore, motivation is a strategy to improve the performance of medical rehabilitation health personnel because the results and the effectiveness of the health personnel performance depend on their motivation.
SUBJECTS AND METHOD

\section{Study Design}

This study used an analytical observational study with a cross-sectional approach using a path analysis model.

\section{Population and Sample}

The population of this study was medical rehabilitation health personnel (medical rehabilitation doctors, medical rehabilitation nurses, physiotherapists, occupational therapists, speech therapists, prosthetic orthotics, medical social workers, psychologists) at Dr.Moewardi Hospital, Surakarta.

\section{Study Variables}

The dependent variable was performance. The independent variables were motivation, skills, work atmosphere, facilities and infrastructure, work experience, training, education, leadership style, incentives, reinforcement, vicarious learning, and observational learning.

\section{Operational Definition of Variables}

Performance was the work that could be achieved by a person or group of people in an organization that is in line with their responsibilities and authorities to achieve organizational goals. The measuring instrument was questionnaires. The data scale was dichotomous data with code $\mathrm{O}=$ poor performance and code 1 =good performance.

Motivationwas the provision of driving force that created excitement for someone so that they were willing to cooperate, work effectively, and integrated with all efforts to achieve satisfaction. The measuring instrument was questionnaires. The data scale was dichotomous data with code $\mathrm{O}=$ low motivation and code $1=$ high motivation .

Skill included technical skill, human skill, conceptual skill, such as the ability to use opportunities, accuracy, using equipment owned by the company in achieving goals. The measuring instrument was questionnaires. The data scale was dichotomous data 
with code $\mathrm{O}=$ no skills and code $1=$ having skills.

Work atmosphere was anything that could affect employees in carrying out duties, including facilities and infrastructure as well as colleagues. The measuring instrument was questionnaires. The data scale was dichotomous data with code $\mathrm{O}=$ non-conducive work atmosphere and code $1=$ conducive work atmosphere.

Facilities and infrastructure was facility was something that could be used as a tool/equipment in achieving the goals and objectives, while infrastructure was something that was a supporting factor for the implementation of an activity. The data scale was dichotomous data with code $\mathrm{o}=$ inadequate facilities and infrastructure and code 1=adequate facilities and infrastructure.

Experience was when someone showed the types of work that someone has done. It provided great opportunities for someone to do a better job. The data scale was dichotomous data with code $\mathrm{O}=$ no experience and code $1=$ having experience.

Training was a process of teaching knowledge, certain skills, and attitudes so that employees were more skilled and able to carry out their responsibilities better based on the standards. The data scale was dichotomous data with code $\mathrm{O}=$ did not attend training and code $1=$ attended training.

Education was everything related to general improvement and understanding of the human environment as a whole and the process of developing knowledge, skills, thoughts, character, and so on. The data scale was dichotomous data with code $\mathrm{O}=$ did not attend special medical rehabilitation education and code $1=$ attended special medical rehabilitation education.

Leadership style was a pattern of behavior showed by the head of the medical rehabilitation department including supportive, participative, achievement-oriented directive styles. The data scale was dichotomous data with code $\mathrm{O}=$ dictator and code $1=$ participative.

Incentive was the number of packages that the organization offered to employees or workers in return for using their energy. The data scale was dichotomous data with code $\mathrm{O}=$ insufficient incentive and code $1=$ sufficient incentive.

Reinforcement was an internal or external response to a person's behavior that affected the likelihood of continuing or stopping the behavior. The data scale was dichotomous data with code $\mathrm{O}=$ negative reinforcement, code $1=$ positive reinforcement.

Vicarious learningwas a learning process that appeared as a function of observing or imitating other behavior. The data scale was dichotomous data with code $\mathrm{O}=$ failed to observe $1=$ succeeded to observe.

Observational learningwas learning by seeing the behavior of others or being a model. The data scale was dichotomous data with code $\mathrm{O}=$ did not have a model code $1=$ have a model.

\section{Study Instruments}

The instrument of this study used questionnaires. The questionnaire in this study consisted of several parts. The questionnaire in this study was in the form of an open and closed questionnaire. The researcher provided the answers in the questionnaire and the respondents only chose the answer according to the condition and filled in according to reality.

\section{Data Analysis}

Univariate analysis was used to describe each dependent variable and the independent variable. The data were classified based on the data type. The continuous data were presented with mean, standard deviation, minimum, and maximum values. The dichotomy data were put into the frequency distribution table.

Bivariate analysis was used to determine the relationship between the indepen- 
dent variable and the dependent variable using the Chi-square test.

Multivariate analysis was used to explain the relationship between the effectsof the variables. Multivariate analysis used path analysis.

\section{Research Ethic}

This study considered the basic principles of research ethics. This study has submitted ethical permission from the Health Research Ethics Commission of Dr.Moewardi Hospital with the Ethical Clearance Number: 294/II/HREC/2020 on March 5, 2020.

\section{RESULTS}

\section{Univariate analysis}

The univariate analysis is described in Table 1 and 2. Table 1 shows this study involved 200 medical rehabilitation health personnel as the study subjects. The results of this study showed that the mean value of the motivation was 11.62 , with a standard deviation by 1.55 , a minimum value by 2 , and a maximum value by 14 . The variable of skill showed that the mean value of the skill was 3.37 , the standard deviation was 1.04, the minimum value was $\mathrm{o}$, and the maximum value was 4 .

Mean score of work atmosphere was 3.85 , the standard deviation was 1.56 , the minimum value was 0 , and the maximum value was 8 . The variable of facility and infrastructure showed that the mean value of faci- lities and infrastructure was 3.18, the standard deviation was 1.24 , the minimum value was 0 , and the maximum value was 6 . The variable of experience showed that the mean value of experience was 4.25 with a standard deviation by 0.94 , a minimum value by 1 , and a maximum value by 6 .

The variable of training and education showed that the mean value of training and education was 11.20 , the standard deviation was 2.10, the minimum value was $\mathrm{o}$, and the maximum value was 16 . The variable of leadership style showed that the mean leadership style was 6.19, the standard deviation was 1.73 , the minimum value was 0 , and the maximum value was 8 . The variable of incentive showed that the mean value of incentive was 8.08, the standard deviation was 2.20 , the minimum value was 0 , and the maximum value was 12 .

Mean score of reinforcement was 2.16, the standard deviation was 1.07 , the minimum value was 0 , and the maximum value was 4. Mean score of vicarious learning and observational learning was 4.59 , the standard deviation was 1.65 , the minimum value was 0 , and the maximum value was 10 . The variable of performance showed that the mean value of the performance of medical rehabilitation health personnel was 22.27, the standard deviation was 3.02, the minimum value was 4 , and the maximum value was 26 .

\section{Table 1. The characteristics of the Subjects (continuous data)}

\begin{tabular}{lccccc}
\hline \multicolumn{1}{c}{ Variable } & n & Mean & SD & Min. & Max. \\
\hline Motivation & 200 & 11.62 & 1.55 & 2 & 14 \\
Skill & 200 & 3.37 & 1.04 & 0 & 4 \\
Work atmosphere & 200 & 3.85 & 1.56 & 0 & 8 \\
Facilities and infrastructure & 200 & 3.18 & 1.24 & 0 & 6 \\
Experience & 200 & 4.25 & 0.94 & 1 & 6 \\
Training \& Education & 200 & 11.20 & 2.10 & 0 & 16 \\
Leadership Style & 200 & 6.19 & 1.73 & 0 & 8 \\
Incentive & 200 & 8.08 & 2.20 & 0 & 12 \\
Reinforcement & 200 & 2.16 & 1.07 & 0 & 4 \\
Vicarious \& Observational Learning & 200 & 4.59 & 1.65 & 0 & 10 \\
The Performance of Medical Rehabilitation & 200 & 22.27 & 3.02 & 4 & 26 \\
Health Personnel & & & & & \\
\hline
\end{tabular}


Sisybania et al./ Job Performance among Medical Rehabilitation Health Personnel

Table 2. The characteristics of the Subjects (dichotomous data)

\begin{tabular}{|c|c|c|}
\hline Characteristic & $\mathbf{n}$ & $\%$ \\
\hline \multicolumn{3}{|l|}{ Motivation } \\
\hline High & 142 & 71.0 \\
\hline Low & 58 & 29.0 \\
\hline \multicolumn{3}{|l|}{ Skill } \\
\hline Fair & 132 & 66.0 \\
\hline Poor & 68 & 34.0 \\
\hline \multicolumn{3}{|c|}{ Work Atmosphere } \\
\hline Conducive & 130 & 65.0 \\
\hline Unconducive & 70 & 35.0 \\
\hline \multicolumn{3}{|c|}{ Facilities and Infrastructure } \\
\hline Adequate & 100 & 50.0 \\
\hline Inadequate & 100 & 50.0 \\
\hline \multicolumn{3}{|l|}{ Experience } \\
\hline Lots & 58 & 29.0 \\
\hline Few & 142 & 71.0 \\
\hline \multicolumn{3}{|c|}{ Training and Education } \\
\hline Yes & 107 & $53 \cdot 5$ \\
\hline No & 93 & 46.5 \\
\hline \multicolumn{3}{|c|}{ Leadership Style } \\
\hline Participative & 88 & 44.0 \\
\hline Authoritative & 112 & 56.0 \\
\hline \multicolumn{3}{|l|}{ Incentive } \\
\hline Sufficient & 85 & 42.5 \\
\hline Insufficient & 115 & $57 \cdot 5$ \\
\hline \multicolumn{3}{|l|}{ Reinforcement } \\
\hline Good & 52 & 26.0 \\
\hline Poor & 148 & 74.0 \\
\hline \multicolumn{3}{|c|}{ Vicarious dan Observational Learning } \\
\hline Good & 79 & 39.5 \\
\hline Poor & 121 & 60.5 \\
\hline \multicolumn{3}{|l|}{ Performance } \\
\hline Good & 117 & 58.5 \\
\hline Poor & 83 & 41.5 \\
\hline
\end{tabular}

Table 2 shows the data of the univariate analysis (dichotomous data) of 200 study subjects. Most of the subjects had high motivation by 142 subjects (71.0\%) and low motivation by 58 subjects (29.0\%).

The subjects who had good skills were 132 subjects (66.0) and those who had poor skills were 68 subjects (34.0\%). Most of the subjects had a good work atmosphere by 130 subjects (65\%) and 70 subjects (35\%) had a poor work atmosphere.

The subjects with adequate facilities and infrastructure were 100 subjects (50.0\%) and the subjects with inadequate facilities and infrastructure were 100 subjects (50.0\%). The subjects who had lots of experience were 58 subjects (29.0\%) and those who did not have much experience were 142 subjects (71.0\%). There were 107 subjects (53.5\%) who attended training and education and 93 subjects (46.5\%) who had did not attend training and education.

The subjects with a participative leadership style were 88 subjects (44.0\%) and the subjects with authoritarian leadership styles were 112 people (56.0\%). The subjects who had sufficient incentives were 85 subjects (42.5\%) and those who had insufficient 
incentives were 115 (57.5\%). The subjects with good reinforcement were 52 subjects (26.0\%) and the subjects with poor reinforcement were 148 subjects (74.0\%).

The subjects with good vicarious and observational learning were 79 subjects (39.5\%) and the subjects with poor vicarious and observational learning were 121 subjects (60.5\%). Most of the subjects with good performance were 117 (58.5\%) and the subjects with poor performance were 83 subjects (41.5\%). This study used the Chi-square test. It explained the relationship between the dependent variable (performance) and the independent variable (motivation, skills, work atmosphere, facilities and infrastructure, experience, training and education, leadership style, incentives, reinforcement, vicarious learning, and observational learning). The results of the bivariate analysis can be seen in Table 3 .

Table 3 shows that there was an effect of motivation on the performance of medical rehabilitation health personnel. The health personnel with high motivation had 3.67 times likelihood of performing well compared to the health personnel who had the low motivation $(\mathrm{OR}=3.67 ; 95 \% \mathrm{CI}=1.85$ to 7.36 ; $\mathrm{p}<0.001)$. The health personnel who had sufficient skills had 1.69 times likelihood of performing well compared to the health personnel who had insufficient skills ( $\mathrm{OR}=1.69$; $95 \% \mathrm{CI}=0.89$ to $3.19 ; \mathrm{p}=0.080$ ).

\section{The result of bivariate analysis}

The health personnel with a conducive working atmosphere had 1.86 times likelihood of performing well compared to the health personnel who had a non-conducive working atmosphere $(\mathrm{OR}=1.86 ; 95 \% \mathrm{CI}=0.99$ to 3.15 ; $\mathrm{p}=0.037)$. The health personnel with adequate facilities and infrastructure had $\mathbf{1 . 8 6}$ times likelihood of performing well compared to the health personnel with inadequate facilities and infrastructure $(\mathrm{OR}=1.86 ; 95 \% \mathrm{CI}=$ 1.01 to $3.43 ; \mathrm{p}=0.031$ ).
The health personnel with a lot of experience had 0.67 times likelihood of performing well compared to the health personnel with few experiences ( $\mathrm{OR}=0.67 ; 95 \%$ $\mathrm{CI}=0.34$ to $1.31 ; \mathrm{p}=0.214)$. The health personnel who attended special medical rehabilitation training and education had 2.84 times likelihood of performing well compared to the health personnel who did not attend special medical rehabilitation training and education $(\mathrm{OR}=2.84 ; 95 \% \mathrm{CI}=1.52$ to 5.31 ; $\mathrm{p}<0.001)$. The health personnel led by the participatory leaders were 3.26 times more likely to perform better than the health personnel led by the authoritarian leaders (OR= 3.26; $95 \% \mathrm{CI}=1.71$ to 6.26 ; $\mathrm{p}<0.001)$.

The health personnel with sufficient incentives were 3.23 times more likely to perform better than the health personnel with insufficient incentives $(\mathrm{OR}=3.23$; 95\% $\mathrm{CI}=1.69$ to $6.25 ; \mathrm{p}<0.001)$. The health personnel with good reinforcement were 1.47 times more likely to perform better than the health personnel with poor reinforcement $(\mathrm{OR}=1.47 ; 95 \% \mathrm{CI}=0.73$ to $3.04 ; \mathrm{p}=0.241)$. The health personnel with a good vicarious and observational learning were 0.75 times more likely to perform better than the health personnel with a poor vicarious and observational learning $(\mathrm{OR}=0.75 ; 95 \% \mathrm{CI}=0.41$ to 1.40; $\mathrm{p}=0.345)$.

\section{The result of multivariate analysis}

Multivariate analysis explained the relationship between the effect of performance on motivation, work atmosphere, training and education, leadership style, incentives, and reinforcement. Table 6 shows that there was a relationship of the effect between variables. These variables could directly or indirectly affect the performance of medical rehabilitation health personnel.

The performance of medical rehabilitation health personnel was directly affected by their leadership style. The health personnel led by the participatory leaders had 
Sisybania et al./ Job Performance among Medical Rehabilitation Health Personnel

2.24 units higher logodd to performbetter

tarian leaders $(b=2.24 ; 95 \% \mathrm{CI}=0.09$ to 1.44 ; than the health personnel led by the authori$\mathrm{p}=0.025$ ).

Table 3. The Chi-square test of factors affecting Health Personnel Performance

\begin{tabular}{|c|c|c|c|c|c|c|c|c|}
\hline \multirow{3}{*}{$\begin{array}{l}\text { Independent } \\
\text { Variable }\end{array}$} & \multicolumn{4}{|c|}{ Job Performance } & \multirow{3}{*}{$\mathbf{O R}$} & \multirow{2}{*}{\multicolumn{2}{|c|}{ 95\% CI }} & \multirow{3}{*}{$\mathbf{p}$} \\
\hline & \multicolumn{2}{|c|}{ Poor } & \multicolumn{2}{|c|}{ Good } & & & & \\
\hline & $\mathbf{N}$ & $\%$ & $\mathbf{N}$ & $\%$ & & $\begin{array}{c}\text { Lower } \\
\text { Limit }\end{array}$ & $\begin{array}{l}\text { Upper } \\
\text { Limit }\end{array}$ & \\
\hline \multicolumn{9}{|l|}{ Motivation } \\
\hline High & 46 & 32.39 & 96 & 67.61 & \multirow{3}{*}{3.67} & \multirow{3}{*}{1.85} & \multirow{3}{*}{$7 \cdot 36$} & \multirow{3}{*}{$<0.001$} \\
\hline Low & 37 & 63.79 & 21 & 36.21 & & & & \\
\hline Skills & & & & & & & & \\
\hline Fair & 49 & 37.12 & 83 & 62.88 & \multirow{3}{*}{1.69} & \multirow{3}{*}{0.89} & \multirow{3}{*}{3.19} & \multirow{3}{*}{0.080} \\
\hline Poor & 34 & 50.00 & 34 & 50.00 & & & & \\
\hline Work Atmosphe & & & & & & & & \\
\hline Conducive & 47 & 36.15 & 83 & 63.85 & \multirow{2}{*}{1.86} & \multirow{2}{*}{0.99} & \multirow{2}{*}{$3 \cdot 51$} & \multirow{2}{*}{0.037} \\
\hline Unconducive & 36 & 51.43 & 34 & 48.57 & & & & \\
\hline \multicolumn{9}{|c|}{ Facilities and Infrastructure } \\
\hline Adequate & 34 & 34.00 & 66 & 66.00 & \multirow{3}{*}{1.86} & \multirow{3}{*}{1.01} & \multirow{3}{*}{3.43} & \multirow{3}{*}{0.031} \\
\hline Inadequate & 49 & 49.00 & 51 & 51.00 & & & & \\
\hline Experience & & & & & & & & \\
\hline Lots & 28 & 48.28 & 30 & 51.72 & \multirow{2}{*}{0.67} & \multirow{2}{*}{0.34} & \multirow{2}{*}{1.31} & 0214 \\
\hline Few & 55 & 38.73 & 87 & 61.27 & & & & 0.214 \\
\hline Training and Edy & & & & & & & & \\
\hline Yes & 32 & 29.91 & 75 & 70.09 & 284 & 152 & 5.31 & $<0.001$ \\
\hline No & 51 & 54.84 & 42 & 45.16 & 2.04 & 1.52 & $5 \cdot 3^{1}$ & -0.001 \\
\hline Leadership Style & & & & & & & & \\
\hline Participative & 23 & 26.14 & 65 & 73.86 & 3.26 & 171 & 6.26 & $<0.001$ \\
\hline Authoritative & 60 & 53.57 & 52 & 46.43 & 3.20 & $1 . / 1$ & 0.20 & 0.001 \\
\hline Incentive & & & & & & & & \\
\hline Sufficient & 54 & 46.96 & 63 & 74.12 & & 160 & 625 & $<0001$ \\
\hline Insufficient & 61 & 53.04 & 22 & 25.88 & 3.23 & 1.09 & 0.25 & $<0.001$ \\
\hline Reinforcement & & & & & & & & \\
\hline Good & 18 & 41.50 & 34 & $65 \cdot 38$ & & & 3.04 & 0.241 \\
\hline Poor & 65 & 43.92 & 83 & 56.08 & 1.47 & 0.73 & 3.04 & 0.241 \\
\hline Vicarious dan $\mathrm{Ob}$ & ttion & 1 Leari & & & & & & \\
\hline Good & 36 & $45 \cdot 57$ & 43 & 54.43 & 0.75 & 0.4 & 1.40 & \\
\hline Poor & 47 & 38.84 & 74 & 61.16 & 0.15 & 0.41 & 1.40 & 0.345 \\
\hline
\end{tabular}

The health personnel with sufficient incentives had 3.19 units higher logodd to perform better than the health personnel with insufficient incentives $(\mathrm{b}=3.19 ; 95 \% \mathrm{CI}=$ 0.42 to $1.76 ; \mathrm{p}<0.001)$. The health personnel who had high motivation had 3.38 units higher logodd to perform better than the health personnel who had low motivation $(\mathrm{b}=3.38$; 95\% CI $=0.51$ to $1.93 ; \mathrm{p}<0.001)$.

The health personnel who attended special medical rehabilitation training and education had a logodd of 1.86 units higher than the health personnel who did not attend special medical rehabilitation training and education $(b=1.86 ; 95 \% \mathrm{CI}=-0.03$ to $1.27 ; \mathrm{p}=$ o.064). The health personnel with a good reinforcement had a logodd of 1.72 units higher than the health personnel with a poor reinforcement $(b=1.72 ; 95 \% \mathrm{CI}=-0.09$ to 1.42; $\mathrm{p}=0.086$ ).

There was an indirect effect of training and education on the performance of medical rehabilitation health personnel through incentives. The result was statistically signifi- 
Sisybania et al./ Job Performance among Medical Rehabilitation Health Personnel

cant. The health personnel who attended training and education had 1.86 units higher logodd to perform better than the health personnel who did not attend training and education $(b=1.86 ; 95 \% \mathrm{CI}=-0.02$ to $1.11 ; \mathrm{p}=$ 0.062).

There was an effect of the work atmosphere on the performance of medical reha- bilitation health personnel through motivation. The result was statistically significant. The health personnel with a conducive working atmosphere had 2.49 units higher logodd to perform better than the health personnel with a non-conducive working atmosphere $(b=2.49 ; 95 \% \mathrm{CI}=0.16$ to $1.42 ; \mathrm{p}=$ 0.013).

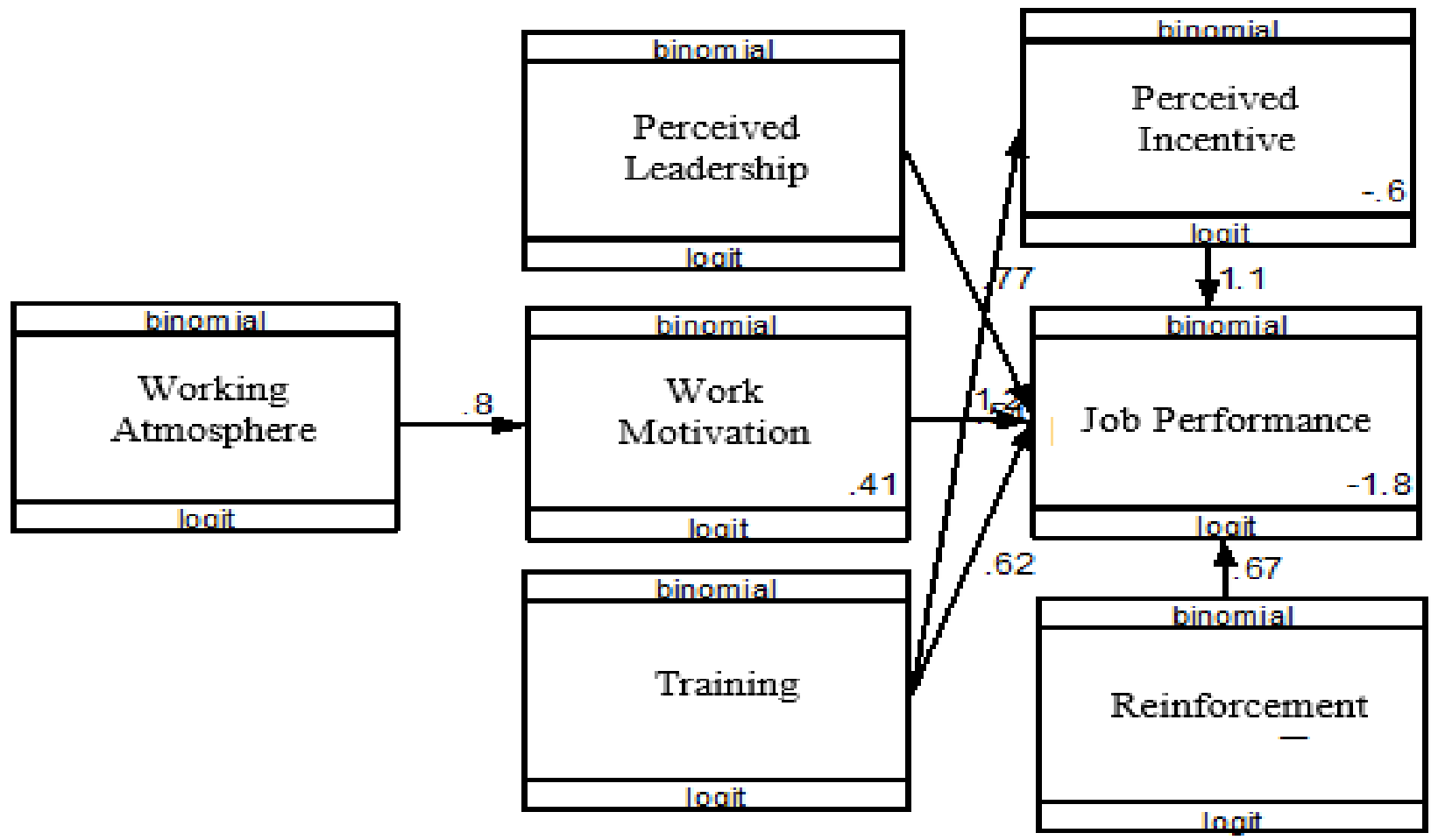

Figure 1. Path model on the determinants of job performance

Table 4. The results of path analysis on the determinants of job performance

\begin{tabular}{|c|c|c|c|c|c|c|}
\hline \multirow[b]{2}{*}{$\begin{array}{c}\text { Dependent } \\
\text { Variable }\end{array}$} & \multirow{2}{*}{\multicolumn{2}{|c|}{ Independent Variable }} & \multirow{2}{*}{$\begin{array}{l}\text { Path } \\
\text { Coef. } \\
\text { (b) }\end{array}$} & \multicolumn{2}{|c|}{$95 \%$ CI } & \multirow[b]{2}{*}{$\mathbf{p}$} \\
\hline & & & & $\begin{array}{c}\text { Lower } \\
\text { limit }\end{array}$ & $\begin{array}{l}\text { Upper } \\
\text { limit }\end{array}$ & \\
\hline \multicolumn{7}{|l|}{ Direct Effect } \\
\hline \multirow[t]{4}{*}{ Job performance } & & $\begin{array}{l}\text { Leadership Style } \\
\text { (participative) }\end{array}$ & 2.24 & 0.09 & 1.44 & 0.025 \\
\hline & & Incentive (sufficient) & 3.19 & 0.42 & 1.76 & $<0.001$ \\
\hline & & Motivation (tinggi) & $3 \cdot 38$ & 0.51 & 1.93 & $<0.001$ \\
\hline & & Training and Education (yes) & 1.86 & -0.03 & 1.27 & 0.064 \\
\hline Indirect Effect & & Reinforcement(good) & 1.72 & -0.09 & 1.42 & 0.086 \\
\hline $\begin{array}{l}\text { Incentive } \\
\text { (sufficient) }\end{array}$ & & Training and Education (yes) & 1.86 & -0.02 & 1.11 & 0.062 \\
\hline \multicolumn{6}{|c|}{$\begin{array}{l}\text { Lopservation }=200 \\
\text { Log likelihood }=-364.66\end{array}$} & 0.013 \\
\hline $\mathrm{p}<0.001$ & & & & & & \\
\hline
\end{tabular}




\section{DISCUSSION}

1. The effect of leadership style on the performance of medical rehabilitation health personnel

The result of this study indicated that there was an effect of leadership style on the performance of medical rehabilitation health personnel. It was statistically significant. The result of the analysis showed that a participatory leadership style improved the performance of medical rehabilitation health personnel $(b=2.24 ; 95 \% C I=0.09$ to $1.44 ; p=$ 0.025).

According to a study conducted by Marwandi et al (2020), there was a significant effect between transformational leaders and the health of members of the health community $(\mathrm{b}=2.23 ; 95 \% \mathrm{CI}=0.94$ to 3.52 ; $\mathrm{p}<0.001)$. The transformational leaders improved the health of members of the health community 2.23 times compared to the leaders who were not transformational.

Based on a study conducted by Nur (2017), transformational leaders had a significant effect on the health of members of the health community $(b=0.29 ; p<0.001)$. This study is in line with a study conducted by Miao and Cao (2019) which used more sample and a larger health community in China, that when employees saw their leadership as transformational, the positive relationship between work well-being and employee creativity was stronger.

\section{The effect of incentive on the performance of medical rehabili- tation health personnel}

The result of this study indicated that there was an effect of incentives on the performance of medical rehabilitation health personnel. It was statistically significant. The result of the analysis showed that sufficient incentives increased the performance of medical rehabilitation health personnel $(b=$ $3.19 ; 95 \% \mathrm{CI}=0.42$ to $1.76 ; \mathrm{p}<0.001)$.
Based on the result of a study conducted by Irwadi et al (2018), incentives would affect nurse performance. High incentives would improve nurse performance ( $\mathrm{OR}=$ 11.12; 95\% $\mathrm{CI}=2.66$ to $46.49 ; \mathrm{p}<0.001)$. This study is in line with a study conducted by Rudasingwa and Uwizeye (2017), that incentives were related to nurse performance. Small incentives and few experiences reduced nurse motivation. As a result, it decreased nurse performance.

Sulaeman (2014) reported the significance of the effect of salary on work productivity. The positive relationship between salary and worker productivity is in line with Leibenstein in Priadana (2010) that worker productivity had a positive relationship with salary paid by companies. Therefore, he suggested, developing countries with relatively higher salary rates could improve health and nutrition standards. It would indirectly increase worker productivity.

\section{The effect of motivation on the performance of medical rehabili- tation health personnel}

The result of this study indicated that there was an effect between motivation and the performance of medical rehabilitation health personnel. It was statistically significant. The result of the analysis showed that high motivation increased the performance of medical rehabilitation health personnel $(b=3.38$; 95\% $\mathrm{CI}=0.51$ to 1.93 ; $\mathrm{p}<0.001$ ).

This is in line with a study conducted by Pundati et al (2018), that there was a positive and significant relationship between motivation and nurse performance $(b=0.91 ; 95 \%$ $\mathrm{CI}=0.15$ to $1.68 ; \mathrm{p}=0.019)$. The result of this study indicated that good nurse motivation affected good nurse performance. Nurse motivation at Dr. Arif Zaenuddin Hospital was good. In addition, they were able to provide care. Therefore, the nurses were able to provide good service to patients. These services were assessment, diagnosis, plan- 
ning, implementation, evaluation, and documentation.

Hee (2016) stated that motivation was very important in improving the performance of nurses at Malaysia Tourism Hospital. Therefore, hospital management should reach a balance between intrinsic and extrinsic rewards to increase nurses motivation. Therefore, nurse performance could be continuously improved.

\section{The effect of training and education on the performance of medical reha- bilitation health personnel}

The results of this study indicated that there was an effect between training and education and the performance of medical rehabilitation health personnel. It was statistically significant. The results of the analysis showed that the health personnel who attended special medical rehabilitation training and education would improve the performance of medical rehabilitation health personnel $(b=$ $1.86 ; 95 \% \mathrm{CI}=-0.03$ to $1.27 ; \mathrm{p}=0.064$ ).

Training aimed to provide additional knowledge and widen knowledge related to providing the best health services for improved performance. However, an evaluation of management and performance results for long-term effect assessment could be carried out to assess the effectiveness of the training. Kato and Kataoka (2017) explained that training improved performance by 5.85 times.

Babigumira et al (2017) explained that many factors affecting the postpartum management of midwives including training, supervision, workload, salary, and health facilities. Training was one way to improve the quality of resources, from formal to informal education. Training was usually carried out for the short term compared to education which was usually carried out for the long term. The education period in training with simulations would increase the accuracy of management (Mbachu et al, 2017).

\section{The effect of reinforcement on the performance of medical rehabili- tation health personnel}

The results of this study indicated that there was an effect of reinforcement on the performance of medical rehabilitation health personnel. The result was statistically significant. The results of the analysis showed that the health personnel who were given good reinforcement would improve the performance of medical rehabilitation health personnel $(b=1.72 ; 95 \% \mathrm{CI}=-0.09$ to $1.42 ; \mathrm{p}=$ o.086).

A study conducted by Zentall et al (2010) showed that general praise ("good drawer") was associated with children who gave up after failing because failure implied a lack of critical traits (e.g. drawing skills). However, non-generic praise ("good job drawing") was related to mastery of motivation because it implied that success was related to effort. However, the children received mixed praise (inconsistent praise). The effect was unclear.

This study examined how inconsistent praise affected two components of motivation, namely self-evaluation and persistence. The result $(\mathrm{N}=135)$ showed that more nongeneric praise was more in line with motivation, but self-evaluation and persistence were indirectly affected by praise $(\mathrm{p}<0.001)$.

It is in line with Palmen et al (2010) that a study focused on a staff performance enhancement in naturalistic training settings aimed at adolescents with autism spectrum disorders. Behavioral skills training, which consisted of instructional and supervisory feedback, was used to improve staff performance in (a) providing positive reinforcement, (b) correcting errors, (c) giving opportunities for students to show target responses (asking for help). 


\section{The effect of work atmosphere on the performance of medical reha- bilitation health personnel}

The results of this study indicated that there was an indirect effect between working atmosphere on the performance of medical rehabilitation health personnel. It was statistically significant. The results of the analysis showed that the health personnel who had a conducive working atmosphere would improve the performance of medical rehabilitation health personnel $(\mathrm{b}=2.49 ; 95 \% \mathrm{CI}=0.16$ to $1.42 ; \mathrm{p}=0.013$ ).

This is in line with a study conducted by Jayanti et al (2019), that the midwives performance was positively affected by the work atmosphere $(b=0.11 ; p=0.004)$. The results of this analysis showed the direct, indirect, and positive effects of midwife performance through motivation.

Work atmosphere was an important sub-variable of extrinsic motivation factors that affected employee performance. Paying attention to the working conditions of employees was important to maintain their motivation. The work atmosphere was strongly affected by the availability and functioning of work equipment, the comfort, and the safety of the workplace. Conducive working atmosphere would motivate employees to do work (Mudayana, 2010).

\section{AUTHOR CONTRIBUTION}

Sisybania played a role as the main researcher who collected the data, formulated the data, designed the study, and conducted a questionnaire reliability test. Bhisma Murti checked the data and analyzed the data. Mahendra Wijaya suggested study discussion and writing techniques.

\section{CONFLICT OF INTEREST}

The authors declare that there is no conflict of interest in the publication of this article.

\section{FUNDING AND SPONSORSHIP}

This study used personal funds from the main researcher.

\section{ACKNOWLEDGEMENT}

We would like to thank Dr. Moewardi Hospital, Surakarta, and all Health Personnel installation of Medical Rehabilitation who have been willing to give their time to become the study subjects.

\section{REFERENCE}

Hee OC, Kamaludin NH, Ping LL (2016). Motivation and job performance among nurse in the health tourism hospital in Malaysia. International Review of Management and Marketing, 6(4).

Irwadi, Zulfendri, Aulia D. (2018). The associations of ward head direction and incentive with nurse performance at Arun LNG Hospital, Lhokseumawe, Aceh. J Health Policy Manage 3(2): 114to117 https://doi.org/10.26911/thej hpm.2018.03.02.08.

Jayanti ND, Tamtomo D, Suleman ES. (2017). Path analysis on the effects of motivation and other factors on midwives performance of preeclampsia management in malang, east java. $\mathrm{J}$ Health Policy Manage 2): 146. https://doi.org/10.26911/thejhpm.2017.02.02.05.

Kato C, Kataoka Y. (2017). Simulation training program for midwives to manage postpartum hemorrhage: a randomized controlled trial. Nurse Education Today, 51: 88-95. https://-doi.org/10.1016/j.nedt.2017.01.005.

Mbachu II, Udigwe GO, Ezeama CO, Eleje GU, Eke AC. (2017). Effect of on-site training on the accuracy of blood loss estimation in a simulated obstetrics environment. International Journal of Gynecology \& Obstetrics, 137(3), 345- 
Sisybania et al./ Job Performance among Medical Rehabilitation Health Personnel

349. https://doi.org/10.1002/ijgo.12133.

Munabi-Babigumira S, Glenton C, Lewin S, Fretheim A, Nabudere. (2017). Factors that influence the provision of intrapartum and postnatal care by skilled birth attendants in low and middle income countries: aqualitative evidence synthesis. Cochrane Database of Systematic Reviews (11). https://doi.org/10.1002/14651858.CDo11558.pub2

Nur MA. (2017). Pengaruh kepemimpinan transformasional terhadap kekompaka n, keterlibatan kerja dan kinerja pegawai (studi penyusunan dokumen perencanaan pembangunan satuan kerja perangkat daerah Kabupaten Kota Baru). Jurnal Bisnis dan Pembangunan, 6(1). Retrieved from https://ppjp.ulm.ac.id.

Marwandi D, Sulaeman ES, Pawito. (2020). Effect of leadership style of the head of the community health center and other determinants on the health personnel performance in Boyolali, Central Java. J Health Policy Manage. 5(1): 74-84. https://doi.org/10.26911/thejhpm.2020.05.01.07.

Oh YS, Lee MJ, Seo BJ. (2019). Relationship between job attitude and job performance of reception staff at general hospital in seoul. Int $\mathrm{J}$ of Bio-Sci and BioTech,7(3), 155-162 http://dx.doi.org/10.14257/ijbsbt.2015.7.3.16.

Palmen A, Didden R, Korziliuz H. (2010). Effectiveness of behavioral skills training on staff performance in a job training setting for high-functioning adolescents with autism spectrum disorders. Research in Autism Spectrum Disorders, (4) 731-740. doi:10.1016/j.rasd.2010.01.012.
Peraturan menteri kesehatan republik indonesia nomor 56. (2014). Tentang klasifikasi dan perizinan rumah sakit. Jakarta: Kemenkes RI.

Pundati TM, Tamtomo D, Sulaeman ES. (2019). Motivation, competence, workload, and their association with nurse performance in Dr. Arif Zaenudin Hospital, Surakarta. J Health Policy Manage. 3(2): 63-70 https://doi.org/10.26911/thejhpm.2018.03.02.01.

Randungan RO, Rattu AJM, Mariaty NW. (2015). Analisis kinerja petugas kesehatan gigi terhadap pelayanan kesehatan gigi dan mulut di poliklinik gigi RSUD Datoe Binangkang Kabupaten Bolaang Mongondow. JIKMU: 5(2a).

Rudasingwa M, Uwizeye MR (2017). Physicians' and nurses' attitudes towards performance-based financial incentives in Burundi: a qualitative study in the province of Gitega. Glob Health Action. 10(1): 1270813. doi: 10.1080/16549716.2017.1270813.

Sulaeman. (2014). Kepemimpinan kepala puskesmas dengan tempat perawatan dan pengaruhnya terhadap kinerja pegawai puskesmas dengan tempat perawatan di Kabupaten Kuningan Jawa Barat. Jurnal Managemen Pelayanan Kesehatan: 12(2):59-67.

Trisnantoro, Listyani.(2018). Jumlah RS Indonesia pertumbuhan RS publik. Jakarta: Kemenkes RI.

Zentall SR, Morris BJ (2010). "Good job, you're so smart": The effects of inconsistency of praise type on young children's motivation. Journal of Experimental Child Psychology. 107(2): 155163. doi:10.1016/j.jecp.2010.04.015. 